\title{
PENGARUH KUALITAS PELAYANAN TERHADAP KEPUASAN PELANGGAN PADA ALLIUM TANGERANG HOTEL (Studi Eksplanatif pada Allium Hotel Tangerang)
}

\author{
Abdul Basit ${ }^{1)}$, Rizky Handayani ${ }^{2)}$ \\ ${ }^{1}$ Program Studi Ilmu Komunikasi FISIP UniversitasMuhammadiyah Tangerang \\ email: basit.umt@gmail.com \\ ${ }^{2}$ Program Studi Ilmu Komunikasi FISIP UniversitasMuhammadiyah Tangerang \\ email: rizkyhandayani12@gmail.com
}

\begin{abstract}
In the current era of globalization, companies are required to have a competitive advantage in order to be able to compete and survive amid the tight of the competition. Therefore, companies need good human resources and able to compete. The background of this research is to find out whether the dimensions of service quality (tangible, reliability, assurance, responsiveness, and emphaty) affect customer satisfaction at Allium Tangerang Hotel. the goal is to find out how much the influence of the independent variable toward the dependent variable, either partially or simultaneously. This research is a quantitative-explanatory research with the research subject Allium Tangerang Hotel. The population in this study were the guests who held an event at Allium Tangerang Hotel. The samples taken were 80 respondents using purposive sampling probability technique. The results show that service quality (X), which includes five variables (Physical Evidence, Reliability, Responsiveness, Assurance, and Attention) is simultaneously related to Customer Satisfaction ( $Y$ ).
\end{abstract}

Keywords: Service quality, tangible, reliability, responsiveness, assurance, emphaty, customer satisfaction

\section{PENDAHULUAN}

Di era globalisasi sekarang ini, informasi yang bersifat publik menjadi kebutuhan mutlak bagi masyarakat. Akses mendapatkan informasi itu sendiri menjadi bagian hak dasar (HAM) yang harus didapatkan setiap manusia di muka bumi. Selain itu, informasi pun harus bersifat transparan, akuntabel dan berkeadilan. Artinya, tidak ada satu pun pihak yang berhak memonopoli informasi untuk kepentingan pribadi atau kelompoknya. Dengan demikian, siapa pun memiliki hak mendapat informasi, mulai dari pegawai, atasan, instansi swasta, pemerintah, hingga masyarakat kelas bawah.

Di sisi lain, kegiatan mengakses informasi tidak bisa lepas dari komunikasi, dan karenanya komunikasi memegang peranan yang penting. Manusia dapat berinteraksi dengan manusia lainnya (baik itu dalam pertukaran informasi maupun pertukaran pengalaman) melalui komunikasi. Melalui sarana/alat komunikasi berupa media, maka manusia bisa mengakses berbagai informasi baik yang bersifat pribadi maupun publik.

Akibat perkembangan teknologi
informasi dan komunikasi ini, yang

menyebabkan manusia memasuki era informasi, perusahaan pun terkena dampaknya, di mana perusahaan dituntut mampu mengembangkan keunggulan kompetitif supaya dapat bersaing secara fair dan kompetitif di tengah pesatnya perkembangan dunia kerja.

Kota Tangerang, yang terletak di bagian Barat Jakarta dan dikeliling oleh daerah Kabupaten Tangerang di bagian Selatan, Barat dan Timur, adalah kota terbesar di Propinsi Banten dan terbesar ketiga di Jabodetabek. Sebagai daerah penyangga DKI Jakarta, kota ini pun turut mengembangkan berbagai potensinya, salah satunya ialah menyediakan komponen pendamping bagi perjalanan bisnis dan juga wisata. Karena itu, berbagai hotel pun makin banyak bermunculan, dan perkembangannya pun sangat pesat. Terlebih, hotel merupakan salah satu bentuk akomodasi serta penunjang wisata.

Sementara itu, dewasa ini pengertian hotel tidak hanya sebatas tempat menginap, melainkan sudah mengalami perkembangan yang pesat, baik dari aspek jenis, karakteristik, pelayanan ataupun fasilitas yang disediakan. Sebab itu, perkembangan hotel 
pun semakin berkembang pesat, mulai dari hotel standar hingga bintang lima.

Hotel di Kota Tangerang sekarang saling bersaing dalam memberi pelayanan terbaik kepada pelanggan yang datang ke hotel mereka. Selain fasilitas yang mendukung yang ada di hotel tersebut, hospitality pegawai hotel kepada pelanggan pun menjadi hal penting lantaran berhubungan dengan penilaian pelanggan terhadap hotel tersebut. Pelanggan yang merasa nyaman dan senang tentunya akan memberi penilaian positif dan bahkan merekomendasikannya kepada orang lain atau keluarga mereka sendiri.

Salah satu hotel yang ada di Tangerang adalah Allium Tangerang Hotel, hotel bintang empat yang dibawahi Samali Hotels \& Resort. Baru berdiri selama kurang lebih 3 tahun, Allium Tangerang Hotel memiliki lokasi yang strategis di pusat kota dan dekat dengan bandara dan pusat

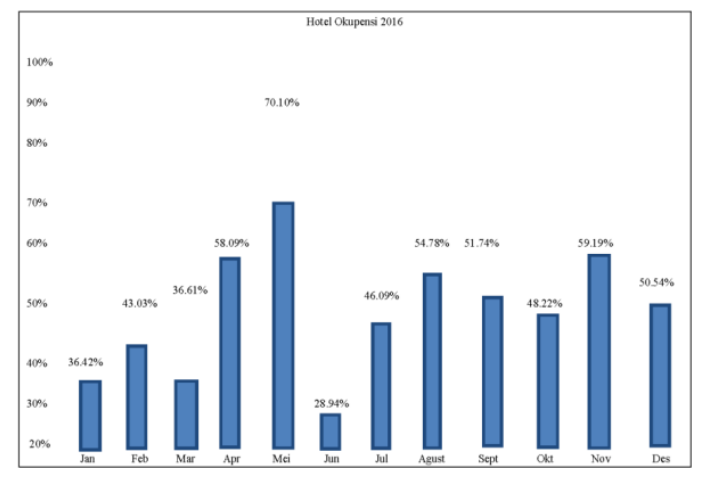

\section{Gambar 1. Tingkat Hotel Okupansi Allium Tangerang Hotel}

Pada Bulan Januari 2016, okupansi Allium Tangerang Hotel 36.24\%. Pada Bulan Februari Allium Tangerang Hotel mengalami peningkatan hingga mencapai $43.03 \%$ dengan mendatangkan beberapa grup besar yang membuat okupansi cukup meningkat dari bulan sebelumnya. Namun, pada Bulan Maret tingkat hunian di beberapa hotel menurun, termasuk Allium Tangerang Hotel yang juga mengalami penurunan okupansi hingga7\%. Pada Bulan April dan Mei Allium Tangerang Hotel terus mengalami peningkatan dengan okupansi mencapai $70.10 \%$, dan bulan Mei 2016 merupakan bulan terbaik bagi Allium Tangerang Hotel dalam tingkat okupansi kamar. perbelanjaan. Allium Tangerang Hotel menyediakan 157 kamar dan sebelas meeting room serta falisitas lainnya, misalnya restoran, swimming pool, dan fitness center. Dengan adanya fasilitas ini, hotel ini berhasil membangun eksistensi industri perhotelan di Kota Tangerang. Hal ini diperkuat dengan komentar-komentar positif dari para pelanggan mengenai fasilitas tersebut.

Struktur bangunan Allium Tangerang Hotel yang miring menjadi daya tarik tersendiri dan menjadi salah satu bangunan yang terkenal di kota Tangerang. Karena memiliki sarana dan fasilitas yang lengkap, Allium Tangerang Hotel pun kerap menjadi pilihan dalam penyelenggaraan berbagai acara. Terlebih, Allium Tangerang Hotel dapat menampung 1250 orang pada suatu kegiatan. Tabel 1 berikut ini memperlihatkan data hotel okupansi Allium Tangerang Hotel periode Januari-Desember 2016.

Pada bulan Juni, Allium Tangerang Hotel mengalami penurunan yang sangat drastis, karena bulan Ramadan merupakan waktu di mana pelanggan menghabiskan waktunya untuk berlibur serta kembali ke kota masing-masing, dan okupansi hotem hanya mencapai 28\%. Kemudian pada periode Juli-Agustus, Allium Tangerang Hotel kembali mengalami peningkatan hingga mencapai $54.78 \%$.

Berdasarkan pemaparan singkat tersebut, peneliti tertarik untuk meneliti pengaruh kualitas pelayanan resepsionis terhadap kepuasan pelanggan Allium Tangerang Hotel yang setiap bulannya mengalami peningkatan dan penurunan okupansi. Allium Tangerang Hotel memiliki departement penting yang beroperasi menjalankan hotel, seperti Front Office, Housekeeping, Food \& Beverage, Engineering, Accounting, Human Resources, Sales \& Marketing, dan Security. Front Office adalah departemen yang paling berpengaruh dalam sebuah hotel lantaran kesan pertama yang akan ditemui oleh pelanggan dari sebuah hotel adalah melalui Front Office Departement. Selain itu, departement ini pun merupakan pusat segala informasi, dan pelanggan akan menyampaikan keluhannya kepada Department Front Office. Dalam hal ini, pelanggan akan melihat secara langsung 
bagaiamana Staff Front Office menangani masalah pelanggan saat check in, check out, kesigapan menangani complain pelanggan, dan memberikan rasa nyaman kepada para pelanggan ketika sedang menginap di hotel.

Karena itu, Departemen Front Office harus punya standar operasional pelayanan pelanggan untuk menunjang kualitas pelayanan terhadapt pelanggan, baik dari sisi pengetahuan produk hotel, cara melayani pelanggan, maupun cara penyelesaian masalah pelanggan. Dalam Departemen Front Office itu sendiri terdapat beberapa subbagian: Reception (Guest service Agent) dan Concierge (Bell Diver).

Berdasarkan latar belakang masalah di atas maka penelitian ini bertujuan untuk mengetahui sekaligus menjelaskan pengaruh kualitas pelayanan resepsionis Allium Tangerang Hotel terhadap kepuasan pelanggan.

Pengertian komunikasi yang disebutkan di atas masih bersifat dasar, dalam arti komunikasi minimal harus mengandung kesamaan makna di antara dua pihak yang terlibat. Dikatakan minimal karena kegiatan komunikasi tidak hanya bersifat informatif (supaya orang lain mengerti dan tahu), tetapi juga bersifat persuasif (agar orang lain bersedia menerima suatu pandangan atau keyakinan, melakukan suatu perbuatan atau kegiatan, dan lain-lain).

Frank Dance (dalam Littlejohn \& Foss, 2009) mengklarifikasikan konsep dasar komunikasi dengan cara menggarisbawahi elemen-elemen yang digunakan untuk membedakan komunikasi. Ia mendapati tiga poin tentang perbedaan konseptual yang penting yang membentuk dimensi-dimensi dasar komunikasi. Dimensi yang pertama ialah tingkat pengamatan atau keringkasan. Beberapa definisi yang ada termasuk bersifat luas dan bebas, sementara yang lainnya terbatas. Dimensi kedua adalah tujuan. Beberapa definisi hanya memasukkan pengiriman serta penerimaan pesan dengan maksud tertentu, sementara yang lainnya tidak memaksakan pembatasan ini. Sementara dimensi ketiga yang digunakn untuk membedakan definisi komunikasi adalah penilaian normatif. Beberapa definisi komunikasi menyertakan pernyataan keberhasilan, keefektifan atau ketepatan,

\section{KAJIAN LITERATUR \\ Komunikasi}

Kata komunikasi (communication) dalam bahasa Inggris berasal dari kata Latin communis, yang artinya sama. Maksudnya ialah sama makna (Effendy, 2001). Jika ada dua orang yang terlibat komunikasi, misalnya dalam bentuk percakapan, komunikasi berlangsung selama ada kesamaan makna mengenai apa yang dipercakapkan itu. Kesamaan bahasa yang digunakan dalam percakapan itu belum tentu menimbulkan kesamaan makna. Maksudnya, mengerti bahasanya saja belum tentu memahami maksud yang dibawakan bahasa tersebut. Jadi percakapan kedua orang itu bisa dikatakan komunikatif jika keduanya, selain mengerti bahasa yang digunakan, juga memahami makna dari bahan yang dipercakapkan tersebut.

sementara definisi lainnya tidak memuat penilaian yang lengkap seperti itu.

Dalam The Structure and Function of Communication in Society, Harold D. Lasswell (1948) menyebutkan bahwa cara yang baik menjelaskan komunikasi adalah dengan menjawab pertanyaan Who Says What In Which Channel to Whom With What Effect? Paradigma Lasswell menunjukkan bahwa komunikasi terdiri atas lima unsur sebagai jawaban dari pertanyaan yang diajukan. Lima unsur tersebut adalah komunikator/sumber, pesan, media/saluran, komunikan/penerima, dan efek. Berdasarkan paradigma Lasswell, komunikasi adalah proses penyampaian pesan oleh komunikator kepada komunikan melalui media tertentu yang memiliki dampak/efek tertentu.

Dalam penelitian ini, pihak pengirim pesan bertindak sebagai bagian untuk meningkatkan pelayanan terhadap pelanggan yang berdampak pada kenaikan revenue. Pesan adalah pemberitahuan baik lisan maupun tulisan, dan dalam penelitian ini, pesan yang ingin disampaikan pada para tamu hotel adalah Allium Tangerang Hotel layak dijadikan sebagai referensi untuk penginapan, seminar, wisuda, dan lain sebagainya, karena mempunyai fasilitas yang memadai. Media merupakan sebuah sarana yang digunakan untuk menyampaikan informasi, baik itu media cetak maupun online. Dalam penelitian ini, media yang dimaksud antara lain adalah 
Majalah Tangerang Live serta media online, seperti Instagram (@alliumtangeranghotel) dan Facebook (Allium Tangerang Hotel). Sementara itu, komunikan adalah pihak penerima pesan dalam sebuah proses komunikasi, yang dalam penelitian ini adalah para tamu hotel. Terakhir, efek merupakan pengaruh yang dirasakan komunikasi setelah menerima pesan dari komunikator, yang dalam penelitian ini adalah efek yang dirasakan pelanggan setelah berkunjung ke Allium Tangerang Hotel.

\section{Public Relations}

Public Relations ialah fungsi manajemen yang membangun dan mempertahankan hubungan yang baik dan bermanfaat antara organisasi dengan publik yang memengaruhi kesuksesan ataupun kegagalan organisasi (Cutlip, Center \& Broom, 2011).

Definisi Public Relations di atas menempatkannya sebagai sebuah fungsi manajemen yang berarti bahwa manajemen di seluruh organisasi harus memperhatikan Public Relations. Definisi ini juga mengidentifikasi pembentukan dan pemeliharaan hubungan baik yang saling menguntungkan antara organisasi dengan publik sebagai basis moral dan etis dari profesi Public Relations. Pada saat yang sama, definisi ini mengemukakan kriteria untuk menentukan apa itu Public Relations serta apa ang bukan Public Relations.

Ruslan (2005) mengartikan Public Relations sebagai suatu fungsi manajemen yang menilai sikap publik, mengidentifikasi kebijaksanaan dan tata cara seseorang atau orang demi kepentingan publik serta merencanakan dan melakukan program kegiatan untuk meraih pengertian, pemahaman, dan dukungan serta penilaian yang baik dari publiknya.

Dalam suatu manajemen organisasi, Public Relations perlu melakukan serangkaian proses agar memperoleh sumbersumber data yang mendukung sehingga program yang dijalankan dapat tepat sasaran. Sebagaimana dinyatakan oleh Sam Black (dalam Rusdianto, 2010), Public Relations is about reputation, perception, credibility, confidence, harmony and seeking mutual understanding, based on truth and fullinformations.
Posisi Public Relations dalam organisasi menjadi amat penting untuk mengantarkan reputasi organisasi. Perjalanan reputasi ini terwujud seharusnya bukan hanya tanggung jawab praktisi Public Relations, namun seluruh bagian di dalam organisasi harus juga merasakan dan bertanggung jawab terhadap pembentukan reputasi organisasi. Selain itu, Public Relations menjadi sebuah sarana dalam menyampaikan informasi kepada publik sehingga mereka tahu apa yang terjadi dalam perusahaan. Keintegrasian seluruh bagian di dalam organisasi akan mempermudah dan memuluskan jalannya reputasi. Integrasi ini terjadi pada bagian marketing communications, management communications, dan organization communications.Ketiga komponen ini harus berintegrasi saat mengkomunikasikan segala sesuatu tentang merek produk atau merek perusahaan dengan satu suara serta secara simultan dan berkelanjutan.

\section{Kualitas Pelayanan}

Kualitas Pelayanan menjadi suatu keharusan yang harus dilakukan perusahaan supaya bisa bertahan dan tetap mendapatkan kepercayaan pelanggan. Pola konsumsi dan gaya hidup pelanggan menuntut mampu memberi pelayanan berkualitas. Lupiyoadi (2001) menyebutkan keberhasilan perusahaan dalam memberi pelayanan yang berkualitas dapat ditentukan dengan pendekatan service quality yang dikembangkan Zeithaml, Parasuraman dan Berry. Service Quality adalah seberapa jauh perbedaan antara harapan dankenyataan yang dialami pelanggan atas layanan yang mereka terima. Sevice Quality dapat diketahui dengan cara membandingkan persepsi pelanggan atas layanan yang benar-benar mereka terima dengan layanan sesungguhnya yang diharapkan. Jika jasa yang diterima melampaui harapan pelanggan maka kualitas jasa dipersepsikan ideal. Sebaliknya, apabila jasa yang diterima lebih rendah daripada yang diharapkan maka kualitas jasa dianggap buruk (Tjiptono, 2015).

Mengacu pada pengertian kualitas pelayanan tersebut, maka konsep kualitas layanan adalah daya tanggap dan realitas dari jasa yang diberikan perusahaan. Dalam hal ini, Kotler menyebutkan bahwa kualitas pelayanan dimulai dari kebutuhan pelanggan 
serta berakhir pada persepsi pelanggan (dalam Wisnalmawati, 2007).

Jadi, kualitas yang baik bukan berdasarkan persepsi penyediaan jasa, melainkan berdasarkan persepsi pelanggan. Kualitas pelayanan mengacu pada penilaianpenilaian pelanggan mengenai inti pelayanan, yaitu si pemberi pelayanan itu sendiri atau keseluruhan organisasi pelayanan. Sebagian besar masyarakat sekarang mulai menampakkan tuntutan terhadap pelayanan prima, mereka tak lagi sekedar membutuhkan produk yang bermutu, tetapi meraka lebih senang menikmati kenyamanan pelayanan (dalam Tasunar, 2006). Karena itu, dalam merumuskan strategi dan program pelayanan, organisasi harus berorientasi pada kepentingan pelanggan dan memperhatikan dimensi kualitasnya (Suratno \& Purnama, 2004).

Pelayanan memainkan peranan yang sangat penting karena merupakan aktivitas pendukung dalam kegiatan perusahaan. Kualitas Pelayanan merupakan perbedaan antara kenyataan dan harapan pelanggan atas pelayanan yang mereka terima. Dalam bisnis jasa, kualitas pelayanan menjadi kunci keberhasilan perusahaan. Terdapat lima dimensi kualitas pelayanan menurut Zeithaml, Parasuraman dan Berry (dalam Lupiyoadi, 2001) sebagaimana berikut ini.

a. Tangibles, yaitu tampakan dari fasilitas fisik, perlengkapan, karyawan dan alat komunikasi yang digunakan oleh sebuah layanan. Untuk layanan produk perbankan misalnya, tangible bisa dilihat dari apakah layanan tersebut memiliki fasilitas yang menarik; apakah para customer service-nya berbusana sopan dan menarik; apakah informasi yang ada di dalam slip penagihan kartu kredit mudah dipahami; dan lain-lain.

b. Reliability, yaitu kemampuan untuk melaksanakan dan memenuhi layanan yang dijanjikan secara akurat. Ini bisa dilihat dari apakah kalau pegawai mengatakan bahwa pengajuan pinjaman Anda sedang diproses dan akan menelepon balik Anda setengah jam lagi, dia akan menelepon Anda setengah jam kemudian. Juga, apakah slip penagihan kartu kredit free of error atau tidak.

c. Responsiveness, yaitu kemampuan dan kemauan membantu pelanggan dan memberikan layanan yang tepat. Jika pelanggan menghadapi masalah dengan kartu kredit atau tabungan, apakah bank dengan cepat menyelesaikannya.

d. Assurance, yaitu pengetahuan dan kemampuan karyawan memberikan trust serta kepercayaan diri. Apakah bank mempunyai reputasi sebagai bank yang bagus; apakah biaya kartu kredit yang dikenakan sesuai dengan pelayanan dan benefit yang diterima pelanggan; apakah bank memberi garansi layanan kartu kreditnya; dan lain sebagainya.

e. Empathy, yaitu perhatian dan pelayanan yang diberikan perusahaan kepada pelanggan.

Saat menciptakan serive quality, Zeithaml, Parasuraman dan Berry mencoba lima dimensi service yang dianggap penting bagi pelanggan. Hasilnya adalah: Tangible (11\%), Reliability (32\%), Responsiveness (22\%), Assurance (19\%) dan Emphaty (16\%).

\section{Kepuasan Pelanggan}

Menurut Tjiptono (2015), ada lima teori yang sering kali digunakan sebagai acuan pada riset kepuasan pelanggan.

1. Expentancy Disconfirmation Model

Model yang dikembangkan dekade 1970an ini mendefinisikan kepuasan pelanggan sebagai evaluasi yang memberikan hasil di mana pengalaman yang dirasakan setidaknya sama baiknya (sesuai) dengan diharapkan. Berdasarkan konsumsi atau pemakaian produk atau merek tertentu dan merek lainnya dalam kelas produk yang sama, pelanggan membentuk harapannya mengenai kinerja seharusnya dari merek yang bersangkutan. Harapan atas kinerja ini lalu dibandingkan dengan kinerja aktual produk (persepsi terhadap kualitas produk atau jasa). Apabila kinerja lebih lebih rendah dari harapan, yang terjadi ialah ketidakpuasan emosional (negatif disconfirmation); jika kinerja cenderung lebih besar dibanding harapan, yang terjadi adalah kepuasan emosional (positif disconfirmation). Jika kinerja sama dengan harapan yang kemudian terjadi konfirmasi harapan (simple disconfirmation/non-satification). Situasi ini terjadi jika kinerja merek, produk, atau 
pemasok tertentu, menyamai harapan kinerja yang rendah sehingga hasilnya bukanlah kepuasan atau ketidakpuasan. Istilah non-satisfication juga dapat dipakai untuk menggambarkan keadaan ini, di mana pelanggan merasa kecewa namun ia juga tidak akan melakukan komplain.

2. Equity Theory

Berdasarkan teori ini, perasaan tidak puas disebabkan keyakinan bahwa norma sosial dilanggar. Dalam teori ini berlaku norma yang menegaskan bahwa setiap pihak dalam pertukaran harus mendapat perlakuan adil atau fair. Jadi, kepuasan terjadi jika rasio hasil dan input setiap pihak dalam pertukaran kurang lebih sama. Sebaliknya, ketidakpuasan terjadi jika pelanggan meyakini bahwa rasio hasil dan inputnya lebih jelek ketimbang perusahaan atau penyedia jasa. Selain itu, kepuasan pelanggan atas transaksi dipengaruhi oleh perbandingan dengan rasio hasil dan input pelanggan lain. Dengan demikian, evaluasi mengenai keadilan keseluruhan (overall equity) pada transaksi pembelian produk sangat berpengaruh terhadap kepuasan/ketidakpuasan pelanggan.

3. Attribution Theory

Teori ini mengidentifikasi proses yang dilakukan seseorang dalam menentukan penyebab aksi atau tindakan dirinya, orang lain, dan objek tertentu. Atribusi ini mampu memengaruhi kepuasan purnabeli seseorang terhadap produk atau jasa tertentu karena atribusi memoderasi perasaan puas atau tidak puas.

4. Assimilation-Contrast Theory

Menurut teori ini, konsumen mungkin menerima penyimpangan (deviasi) dari ekspektasinya dalam batas tertentu. Apabila produk atau jasa yang dibeli serta dikonsumsi tidak terlalu berbeda dengan apa yang diharapkan pelanggan maka kinerja produk/jasa itu akan diasimilasi/diterima dan produk atau jasa itu dievaluasi secara positif (dinilai memuaskan). Akan tetapi, jika kinerja produk atau jasa malah melampaui zona penerimaan konsumen (zone of acceptance), perbedaan yang ada akan dikontraskan sehingga akan tampak lebih besar. Setiap pelanggan berbeda-beda dalam toleransi terhadap penyimpangan dari kinerja yang diharapkannya, sedangkan sebagian konsumen lebih toleran dibandingkan dengan konsumen lainnya.

\section{Opponent Process Theory}

Teori ini ingin menjelaskan mengapa pengalaman konsumen yang pada mulanya memuaskan kemudian cenderung dievakuasi kurang memuaskan pada kejadian atau kesempatan berikutnya. Dasar pemikirannya adalah pandangan bahwa organisme akan beradaptasi dengan stimulus di lingkungannya sehingga stimulus berkurang intensitasnya sepanjang waktu.

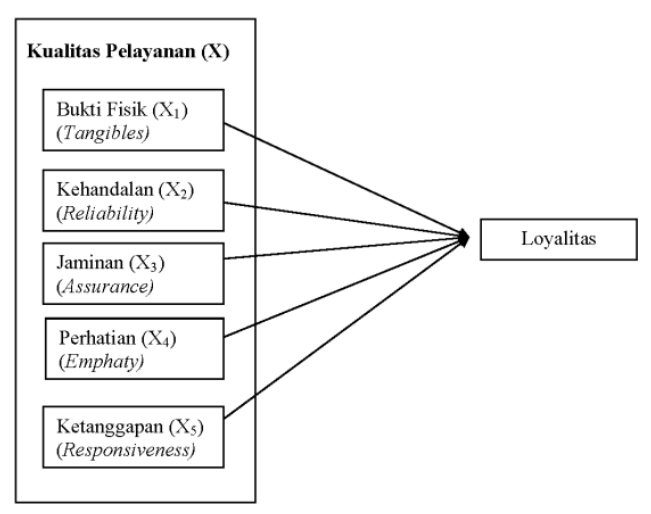

Gambar 2. Kerangka Berpikir

\section{METODE PENELITIAN}

Dalam penelitian ini, peneliti menggunakan tipe penelitian kuantitatif eksplanatif, di mana penelitian ini tidak menitikberatkan pada kedalaman data, melainkan hanya merekam data sebanyakbanyaknya dari populasi yang luas. Dalam penelitian ini ingin diketahui serta dijelaskan apakah ada pengaruh kualitas pelayanan terhadap pelanggan di Allium Tangerang Hotel. Sementara itu, dalam penelitian ini populasinya adalah para pelanggan Allium Hotel Tangerang yang mengadakan event di Allium Tangerang Hotel, yaitu sebanyak 296 orang. Dari populasi tersebut, kemudian ditetapkan sebanyak 80 orang menjadi responden dalam penelitian ini.

\section{HASIL DAN PEMBAHASAN}

Kuesioner di dalam penelitian ini disebarkan kepada 80 responden yang dipilih berdasarkan jenis kelamin dan usia 
sebagaimana dapat dilihat pada Tabel 2 . berikut ini.

Tabel 1. Profil Responden Berdasarkan Jenis Kelamin

\begin{tabular}{cccc}
\hline No & $\begin{array}{c}\text { Jenis } \\
\text { Kelamin }\end{array}$ & $\begin{array}{c}\text { Jumlah } \\
\text { Responden }\end{array}$ & Persentase \\
\hline 1 & Pria & 33 & $41 \%$ \\
2 & Wanita & 47 & $59 \%$ \\
& Jumlah & 80 & $100 \%$ \\
\hline
\end{tabular}

\section{Sumber: Data Diolah Peneliti}

Berdasarkan tabel tersebut, jumlah responden wanita adalah sebanyak 47 orang (59\%), dan jumlah responden laki-laki sebanyak 33 orang $(41 \%)$. Dalam penelitian ini jenis kelamin perempuan lebih mendominasi karena sebagian besar pelanggan yang mengadakan acara di Allium Tangerang Hotel adalah wanita.

Tabel 2. Profil Responden Berdasarkan Usia

\begin{tabular}{cccc}
\hline No & Usia & $\begin{array}{c}\text { Jumlah } \\
\text { Responden }\end{array}$ & Persentase \\
\hline 1 & $\begin{array}{c}<20 \\
\text { Tahun }\end{array}$ & 7 & $8 \%$ \\
2 & $\begin{array}{c}20-30 \\
\text { Tahun }\end{array}$ & 38 & $48 \%$ \\
3 & $\begin{array}{c}30-50 \\
\text { Tahun } \\
4\end{array}$ & 30 & $38 \%$ \\
& $\begin{array}{c}>50 \\
\text { Tahun }\end{array}$ & 5 & $6 \%$ \\
& & 80 & $100 \%$ \\
\hline
\end{tabular}

\section{Sumber: Data Diolah Peneliti}

Berdasarkan tabel di atas, terlihat bahwa jumlah responden terbanyak berdasarkan usia ialah rentang usia 20-30 tahun, yaitu sebesar 38 orang (48\%), berturutturut diikuti rentang usia 30-50 sebanyak 30 responden (38\%), usia $\leq$ sebanyak 7 responden $(8 \%)$, dan usia $\geq$ sebanyak 5 responden $(6 \%)$. Variasi jumlah responden itu disebabkan karena responden menggunakan Allium Tangerang untuk berbagai acara formal dan informal.

Sementara itu, untuk mengetahui seberapa besar pengaruh variabel-variabel bebas terhadap variabel terikat dapat dilihat dari nilai koefisien determinasi sebagaimana pada Tabel 4. berikut ini.

Tabel 3. Koefisien Determinasi

\begin{tabular}{ccccc}
\multicolumn{4}{c}{ Model Summary $^{\mathbf{b}}$} \\
\hline $\begin{array}{c}\text { Mode } \\
\text { l }\end{array}$ & $\mathbf{R}$ & $\begin{array}{c}\mathbf{R} \\
\text { Squar } \\
\mathbf{e}\end{array}$ & $\begin{array}{c}\text { Adjuste } \\
\mathbf{d} \mathbf{R} \\
\text { Square }\end{array}$ & $\begin{array}{c}\text { Std. } \\
\text { Error } \\
\text { of the } \\
\text { Estimat } \\
\mathbf{e}\end{array}$ \\
\hline 1 & $\begin{array}{c}.407 \\
\mathrm{a}\end{array}$ & .166 & .110 & 2.29469
\end{tabular}

a. Predictors:

(Constans), VAR00

005,VAR00004,V

AR00002,VAR00

003

b. Dependent

Variable:

VAR00006

\section{Sumber: Data Diolah Peneliti}

Berdasarkan hasil perhitungan regresi bisa diketahui bahwa koefisien determinasi ( $\mathrm{R}$ square) yang diperoleh adalah sebesar 0,166. Hal ini berarti bahwa keandalan, daya tanggap, jaminan, dan kepedulian berpengaruh sebesar 16,6\% terhadap kepuasan pelanggan sementara sisanya dipengaruhi oleh faktor lain yang tidak diteliti dalam penelitian ini. Adapun Uji F digunakan untuk mengetahui apakah variabel kualitas pelayanan dan kepuasan secara simultan berpengaruh terhadap Kepuasan Pelanggan Allium Tangerang Hotel.

Tabel 4. Uji F

\begin{tabular}{lcccrr}
\multicolumn{6}{c}{ ANOVA $^{\text {a }}$} \\
\hline Model & $\begin{array}{c}\text { Sum } \\
\text { of } \\
\text { Squar } \\
\text { es }\end{array}$ & $\begin{array}{c}\text { D } \\
\text { f }\end{array}$ & $\begin{array}{c}\text { Mean } \\
\text { Squa } \\
\text { re }\end{array}$ & & Sig. \\
\hline Regressi & 77.532 & 5 & 15.50 & 2.94 & 0.1 \\
on & & & 6 & 5 & $8^{\mathrm{b}}$ \\
Residual & 389.65 & 7 & 5.266 & & \\
& 6 & 4 & & & \\
Total & 467.18 & 7 & & & \\
& 8 & 9 & & & \\
\hline
\end{tabular}

a. Dependent Variable: VAR00006 


\section{b. Predictors: (Constans), VAR00005, VAR00001， VAR00004, VAR0002, VAR00003}

\section{Sumber: Data Diolah Peneliti}

Berdasarkan hasil uji simultan (Uji F) diperoleh $\mathrm{F}$ hitung $=2,945$, dengan nilai signifikansi 0,018. Karena nilai signifikansi < 0,05 dan $\mathrm{F}$ Hitung lebih besar dari $\mathrm{F}$ Tabel $(2,37)$ maka hipotesis menyatakan bahwa secara simultan variabel bebas (kualitas pelayanan, fasilitas fisik, dan promosi) berpengaruh signifikan terhadap kepuasan pelanggan Allium.

\section{Tabel 5. Uji T}

\begin{tabular}{ccc}
\multicolumn{3}{c}{ Coefficient $^{\mathbf{a}}$} \\
\hline Model & T & Sig \\
\hline (Constant) & 4.721 & .000 \\
VAR00001 & -.661 & .551 \\
VAR00002 & -.593 & .555 \\
VAR00003 & -.836 & .406 \\
VAR00004 & 3.215 & .002 \\
VAR00005 & -.606 & .547 \\
\hline
\end{tabular}

a. Dependent Variable: VAR00006

\section{Sumber: Data Diolah Peneliti}

Berdasarkan Tabel 6. di atas, dapat dijelaskan sebagaimana berikut ini.

a. Untuk variabel $\mathrm{X}_{1}$ diperoleh $\mathrm{T}$ hitung sebesar -0,661 dengan nilai signifikansi 0,551. Karena $\mathrm{T}$ hitung jauh lebih kecil dari $T$ tabel $(1,993)$, keputusan hipotesis Uji T adalah HO diterima, dan Ha ditolak. Dengan demikian, bukti fisik tak berpengaruh secara signifikan terhadap pelayanan Allium Tangerang Hotel.

b. Untuk variabel $\mathrm{X}_{2}$ diperoleh $\mathrm{T}$ hitung sebesar -0.593 dengan nilai signifikansi 0,555. Karena $\mathrm{T}$ hitung jauh lebih kecil dari $\mathrm{T}$ tabel $(1,993)$, keputusan hipotesis Uji T adalah H0 diterima, dan Ha ditolak. Dengan demikian, keandalan tak berpengaruh secara signifikan terhadap pelayanan Allium Tangerang Hotel.

c. Untuk variabel $\mathrm{X}_{3}$ diperoleh $\mathrm{T}$ hitung sebesar -0.836 dengan nilai signifikansi 0,046. Karena T hitung jauh lebih kecil dari $\mathrm{T}$ tabel $(1,993)$, keputusan hipotesis
Uji T adalah $\mathrm{H} 0$ diterima, dan Ha ditolak. Artinya, ketanggapan tak berpengaruh secara signifikan terhadap pelayanan Allium Tangerang Hotel.

d. Untuk variabel $\mathrm{X}_{4}$ diperoleh $\mathrm{T}$ hitung sebesar 3,215 dengan nilai signifikansi 0,002 . Karena $\mathrm{T}$ hitung jauh lebih besar dari $\mathrm{T}$ tabel $(1,993)$, keputusan hipotesis Uji T adalah H0 ditolak, dan Ha diterima. Artinya, Jaminan berpengaruh secara signifikan terhadap pelayanan Allium Tangerang Hotel.

e. Untuk variabel $\mathrm{X}_{5}$ diperoleh $\mathrm{T}$ hitung sebesar -0. 606 dengan nilai signifikansi 0,547. Karena $\mathrm{T}$ hitung jauh lebih kecil dari $\mathrm{T}$ tabel $(1,993)$, keputusan hipotesis Uji T adalah H0 diterima, dan Ha ditolak. Dengan demikian, perhatian tidak berpengaruh secara signifikan terhadap pelayanan Allium Tangerang Hotel.

Secara umum penelitian ini menunjukan hasil yang cukup mengejutkan, di mana perusahaan harus dapat memperbaiki kualitas pelayanan. Hasil analisis deskriptif menunjukan bahwa kualitas pelayanan yang diberikan Allium Tangerang Hotel belum maksimal. Hal ini ditunjukkan banyaknya tanggapan responden yang menyatakan kurang puas terhadap pelayanan Allium Tangerang Hotel. Melalui Uji F dinyatakan bahwa secara bersama-sama beberapa variabel bebas kualitas pelayanan berpengaruh terhadap kepuasan pelanggan dengan hasil 2,945. Dengan pelayanan yang berkualitas, kepuasan dalam diri pelanggan akan terbangun (Adhitama, Kusumawati dan Abdillah, 2017; Aryani \& Rosinta, 2010; Boavida, 2017; Hidayat \& Basit, 2018).

Lupioadi (2001) menyebutkan bahwa keberhasilan perusahaan dalam memberikan layanan yang berkualitas dapat ditentukan dengan pendekatan kualitas pelayanan yang telah dikembangkan oleh Zeithaml, Parasuraman dan Berry. Teori kepuasan pelanggan untuk produk/layanan dengan kualitas layanan yang sama dapat memberi tingkat kepuasan yang berbeda beda terhadap pelanggan. Oleh karena itu, perusahaan harus selalu memperhatikan kualitas pelayanan yang diberikan kepada pelanggan sebagaimana dilakukan Allium Tangerang Hotel. 
Hasil dari penelitian ini menunjukan bahwa variabel bukti fisik tidak berpengaruh signifikan terhadap kepuasan pelanggan. Sebagaimana dikatakan oleh Tjiptono (2015) metode survei kepuasan pelanggan dapat menggunakan pengukuran di mana responden diminta untuk menuliskan masalah-masalah yang berkaitan dengan penawaran dari perusahaan serta menuliskan perbaikanperbaikan yang mereka rasakan.

Dengan kata lain, bukti fisik pada beberapa indikator menunjukkan perlu adanya perbaikan supaya tercipta kepuasan pelanggan secara maksimal. Semakin kuat upaya Allium Tangerang Hotel membuat pelanggan semakin nyaman, aman terhadap fasilitas yang diberikan, maka semakin tinggi pula tingkat kepuasan pelanggan.

Hasil penelitian juga menunjukkan bahwa variabel keandalan tidak berpengaruh signifikan terhadap kepuasan pelanggan. Menurut Kotler (2000) kepuasan adalah perasaan senang atau kecewa seseorang yang hadir setelah membandingkan kinerja (hasil) produk yang dipikiran dengan kinerja atau hasil yang diharapkan. Dimensi keandalan memiliki nilai signifikansi rendah lantaran Standar Operasional Prosedur yang diterapkan terhadap pegawai kurang konsisten untuk meningkatkan kepuasan pelanggan. Oleh karena itu, beberapa upaya perbaikan diperlukan dengan adanya hasil dan analisis yang dilakukan dalam penelitian ini.

Hasil penelitian menunjukkan bahwa variabel daya tanggap tidaklah berpengaruh signifikan terhadap kepuasan pelanggan. Menurut Smith (dalam Tjiptono, 2015), loyalitas pelanggan tidak bisa tercipta begitu saja. Dengan kata lain, daya tanggap pegawai masih kurang maksimal karena adanya keterbatasan kuantitas sumberdaya manusia. Dalam perspektif kualitas pelayanan pelanggan, Allium Tangerang Hotel bersedia membantu pelanggan dalam hal apa pun, menjawab keluhan dan memberi solusi.

Hasil penelitian ini juga menunjukkan jika variabel jaminan memiliki pengaruh yang positif dan signifikan terhadap kepuasan pelanggan. Hasil ini memberikan bukti empiris bahwa jaminan dari penyedia jasa pelayanan akan memberikan peningkatan kepuasan pelanggan. Menurut Rustanto (dalam Tasunar, 2006) kualitas pelayanan mengacu pada penilaian penilaian pelanggan tentang inti pelayanan. Hal ini ditunjukan dengan kemampuan pegawai dalam melayani pelanggan, pegawai yang mempunyai pengetahuan luas dan jaminan keamanan yang diberikan akan memberikan kesan yang lebih baik pada Allium Tangerang Hotel sehingga meningkatkan kepuasan pelanggan.

Hasil penelitian juga menunjukkan bahwa variabel kepedulian tidak berpengaruh signifikan terhadap kepuasan pelanggan. Meningkatnya kuantitas pengunjung Allium Tangerang Hotel malah berbanding terbalik dengan infrastruktur dan kuantitas sumberdaya manusia dalam proses pelayanan kepada pelanggan. Karena itu, jika ingin terbangun komunikasi yang baik, maka fungsi komunikasi harus dijalankan dengan baik di tengah keterbatasan yang menyebabkan nilai rendah pada kepuasan pelanggan.

\section{KESIMPULAN}

Hasil penelitian ini menunjukkan jika 4 variabel kualitas pelayanan (X) tidak berpengaruh secara signifikan terhadap kepuasan pelanggan. Dengan kata lain, beberapa indikator menunjukkan perlunya upaya perbaikan untuk mewujudkan kepuasan pelanggan secara maksimal. Jadi, semakin kuat Allium Tangerang Hotel membuat pelanggannya nyaman dan aman terhadap berbagai faslitas yang tersedia maka semakin tinggi tingkat kepuasan pelanggan. Sementara itu, terdapat 1 variabel kualitas pelayanan, yaitu jaminan, yang berpengaruh positif dan signifikan bagi kepuasan pelanggan hotel. Hal ini salah satunya diperlihatkan kemampuan pegawai ketika melayani pelanggan dan juga pengetahuan luas serta jaminan keamanan yang diberikan. Artinya, profesionalisme di dalam ruang lingkup kerja seperti ini harus dapat dijaga dan terus dioptimalkan untuk menunjukkan standarisasi kerja Allium Tangerang Hotel.

\section{REFERENSI}

Adhitama, Radhitya, Andriani Kusumawati, dan Yusri Abdillah. (2017). "The Influence of Service Quality on Brand Image and Customer Satisfaction in Airlines Services (Survey of The Garuda Indonesia Passenger Domiciled in Malang, East Java)". Jurnal Administrasi Bisnis (JAB), 23(1): 122-130. 
Aryani, Dwi dan Febrina Rosinta. (2010). "Pengaruh Kualitas Layanan terhadap Kepuasan Pelangga dalam Membentuk Loyalitas Pelanggan, Bisnis \& Birokrasi”. Jurnal Ilmu Administrasi dan Organisasi, 17(2): 114-126.

Boavida, Artur Avila de Jesus. (2017). "Pengaruh Kualitas Pelayanan terhadap Kepuasan dan Loyalitas Nasabah Banco Nacional Comercio Timor Leste (BNCTL)". E-Jurnal Ekonomi dan Bisnis Universitas Udayana, 6(11): 3857-3886.

Cutlip, Scott. M., Allen H. Center dan Glen M. Broom. (2011). Effective Public Relations. New Jersey: Prentice Hall Inc.

Effendy, Onong Uchjana. (2001). Ilmu Komunikasi: Teori dan Praktek. Bandung: PT. Remaja Rosdakarya.

Graha Ilmu.

Hidayat, Ryan dan Abdul Basit. (2018). "Pengaruh Service Excellence terhadap Brand Equity pada Pelanggan Batik Air". Nyimak Journal of Communication, 2(1): 1735.

Kotler, Philip. (2000). Manajemen Pemasaran. Jakarta: Prenhalindo.

Lasswell, Harold D. (1948). The Structure and Function of Communication in Society. New York: Harper \& Bros. Littlejohn, Stephen W. dan Karen A. Foss. (2009). Teori Komunikasi. Jakarta: Penerbit Salemba Humanika.

Nanang, Tasunar. (2006). "Kualitas Pelayanan sebagai Strategi Menciptakan Kepuasan pada Pangkalan Pendaratan Ikan (PPI) Morodemak". Jurnal Sains Pemasaran Indonesia, 5(1): 41-62.

Rambat, Lupiyoadi. (2001). Manajemen Pemasaran Jasa. Jakarta: Salemba Empat. Rusdianto, Ujang (2013). CSR Communications: A Framework of PR Practitioner. Yogyakarta:

Ruslan, Rosady. (2005). Manajemen Humas dan Manajemen Komunikasi: Konsep dan Aplikasinya. Jakarta : Raja Grafindo Persada.

Suratno, Sri dan Nursya' Bani Purnama. (2004). "Analisis Tingkat Kepuasan Wajib Pajak Terhadap Kualitas
Layanan Kantor Pelayanan Pajak Yogyakarta Dua”. Sinergi Kajian Bisnis dan Manajemen, 7(1): 69-87.

Tjiptono, Fandy. (2015). Strategi Pemasaran. Yogyakarta: Penerbit Andi.

Wisnalmawati. (2005). "Pengaruh Persepsi Dimensi Kualitas Layanan terhadap Niat Pembelian Ulang". Jurnal Ekonomi dan Bisnis, 3(10): 153-165. 